\title{
Design of a bubble-swarm bioreactor for animal cell culture
}

\author{
F. Gudermann, D. Lütkemeyer and J. Lehmann \\ Institute of Cell Culture Technology, University of Bielefeld, P.O. Box 100131, 33501 Bielefeld, Germany
}

Key words: Aeration, stirred bioreactor, bubble-swarm, hybridoma, oxygen transfer

\begin{abstract}
A stationary bubble-swarm has been used to aerate a mammalian cell culture bioreactor with an extremely low gas flow rate. Prolonging the residence time of the gas bubbles within the medium improved the efficiency of the gas transfer into the liquid phase and suppressed foam formation. An appropriate field of speed gradients prevented the bubbles from rising to the surface. This aeration method achieves an almost $90 \%$ transfer of oxygen supplied by the bubbles. Consequently, it is able to supply cells with oxygen even at high cell densities, while sparging with a gas flow of only $0.22 \cdot 10^{-3}-1.45 \cdot 10^{-3} \mathrm{vvm}(30-200 \mathrm{ml} / \mathrm{h})$.

The reactor design, the oxygen transfer rates and the high efficiency of the system are presented. Two repeated batch cultures of a rat-mouse hybridoma cell line are compared with a surface-aerated spinner culture. The used cell culture medium was serum-free, either with or without BSA and did not contain surfactants or other cell protecting agents. One batch is discussed in detail for oxygen supply, amino acid consumption and specific antibody production.
\end{abstract}

\section{Introduction}

The aeration of mammalian cell cultures by conventional direct gas sparging presents several problems. First there is the low efficiency of existing aeration units, which require high gas volume flow rates in order to transfer the appropriate quantity of oxygen into the culture broth. This leads to a high gas flow rate through the liquid surface and thus to foam formation. So the use of pure oxygen is frequently necessary to aerate high density cell cultures sufficiently. Increasing the efficiency of the aeration unit will reduce the net gas flows, therefore costs can be lowered.

Another serious problem is excessive foam formation, resulting in damage to the cultured cells. The negative effects of an increasing gas flow rate on animal cell cultures were first discussed by Handa et al., 1985 . The degree of cell damage has been linked to bubble size by Oh et al., 1992 and Jöbes et al., 1991. Zhang et al., 1992, localized the lethal region in a bubble column reactor. They showed like Handa-Corrigan et $a l ., 1989$, that cell damage occurs mainly at the liquid surface and in the foam layer. The main mechanisms causing this damage are the rapid bubble bursts with relatively high energy release, the shearing of cells in draining liquid films between bubbles in the foam and the physical loss of cells.

Surface active substances used for foam regulation and cell protection could have the disadvantage of a reduction in mass transfer (Prins and van 't Riet, 1987). Not only the transfer of gases in and out of the culture broth may be adversely affected but also the uptake of water soluble nutrients from the medium by the cells. Zhang et al., 1992 stated that adsorption of antifoam agent, e.g. a hydrophobic water-insoluble silicone emulsion, occurs at the hydrophobic sites of cell surfaces and may cause the formation of a layer on the cell membrane. At sufficiently high concentrations this layer could resist the transport of water soluble nutrients into the cell.

Another important point is the product separation from the culture broth at the end or during the cultivation. To simplify the down-stream processing a defined and minimized medium composition is desirable (Jäger 
et al., 1991). The absence of FCS, antifoam or Pluronic F-68 simplifies the separation procedure and therefore reduces costs.

One can summarize that neither bubble formation nor bubble rise but bursting of bubbles at the surface is the major mechanism of cell damage in a bubble aerated bioreactor. Surfactants should not be used, so an alternative foam preventing concept has to be designed with regard to the special demands of animal cells.

The basic idea of this concept is the improvement of the oxygen transfer due to prolongation of the residence time of gas bubbles within the medium. This would lead to a drastic decrease of the gas flow rate into the liquid and a better utilization of the bubbles' oxygen content. Hence, if the overwhelming amount of oxygen, brought as gas bubbles into the medium, can be dissolved, there will be only a neglectable foam formation.

An appropriate, downward directed liquid stream had to be generated e.g. in the central part of the culture vessel, to prevent the bubbles from rising to the liquid surface. The velocity field had to prevent bubbles within a certain range of diameter from reaching the surface, so a bubble-swarm will be formed at a defined region in the bioreactor. Therefore, the downward directed liquid velocity has to be high - up to $25 \mathrm{~cm} / \mathrm{s}$ to prevent the largest bubbles from rising - in the upper and as low as possible in the lower part of the stream field - to keep small bubbles. The high liquid velocity probably affects growth and production rates of a cell culture adversely due to hydrodynamical forces. As it is well known that a culture medium with low protein content increases shear sensitivity of animal cells (Ozturk et al., 1991; Hülscher et al., 1988) two cultivations of a hybridoma cell line were carried out with different medium formulations. A serum- and BSA-free medium was first used and a BSA (bovine serum albumin) containing serumfree medium afterwards. The results of these two cultivations in the bubble-swarm aerated bioreactor were compared to those, obtained with a surface aerated spinner culture, which guarantees almost ideal cultivation conditions, especially without critical shear forces. Also the capacity of the bubble-swarm aeration and the efficiency of the system are discussed and compared with conventional bubble columns.

\section{Materials and methods}

Cells

The cell line used in this study is a rat-mouse hybridoma (HB 58, ATCC). This cell line secretes a rat monoclonal antibody $\mathrm{IgG}_{1}$ type specific for mouse antibody $\kappa$ light chains. The cells were precultivated in T-flasks, in spinner (Techne, Cambridge, UK) and in a membrane aerated Super Spinner with a working volume of 1 liter (Lehmann et al., 1992; Heidemann et al., 1994) stirred at $38 \mathrm{rpm}$ in a standard $\mathrm{CO}_{2}$ incubator (Heraeus, Hanau, FRG) at $5 \% \mathrm{CO}_{2}$ and $37^{\circ} \mathrm{C}$.

\section{Medium}

Two medium formulations were used: Medium A is a BSA- and serum-free medium (Jäger et al., 1988). It consists of a 1:1 mixture of DMEM and Hams's F12 (Gibco, Eggenstein, FRG) and is supplemented with $50 \mu \mathrm{M}$ ethanolamine, $2 \mathrm{mM}$ sodium pyruvate, $10 \mathrm{mg} / \mathrm{l}$ human transferrin (Fe saturated) and $10 \mathrm{mg} / \mathrm{l}$ bovine insulin. Except for an addition of $500 \mathrm{mg} / \mathrm{BSA}$ medium $B$ is of the same formulation as medium $A$.

\section{Analytical method}

Two samples per day were taken from the bioreactor vessel and analyzed as follows; the cell number was counted microscopically by trypan blue exclusion. Glucose and lactate were analyzed using the YSI 2700 analyzer (Yellow Springs Instruments, Ohio, USA).

Ammonium was determined using an ammonia selective electrode with microprocessor $\mathrm{pH} /$ Ion meter pMX 2000 (WTW, Weilheim, FRG). The free amino acids contained in the sample were analyzed by an automated reversed phase HPLC system (Kontron, Neufahrn, FRG) with pre-column derivatization using the OPA method (Büntemeyer et al., 1991). Antibody concentration in the supernatant was analyzed using a kinetic sandwich ELISA method and the EL 311 autoreader (Tecnomara, Fernwald, FRG).

\section{Bioreactor concept}

The used bioreactor vessel is a Biostat MD glass fermenter (B. Braun Biotech International GmbH, Melsungen, FRG) with a total volume of 3 liters that was modified as shown in Fig. 1. 


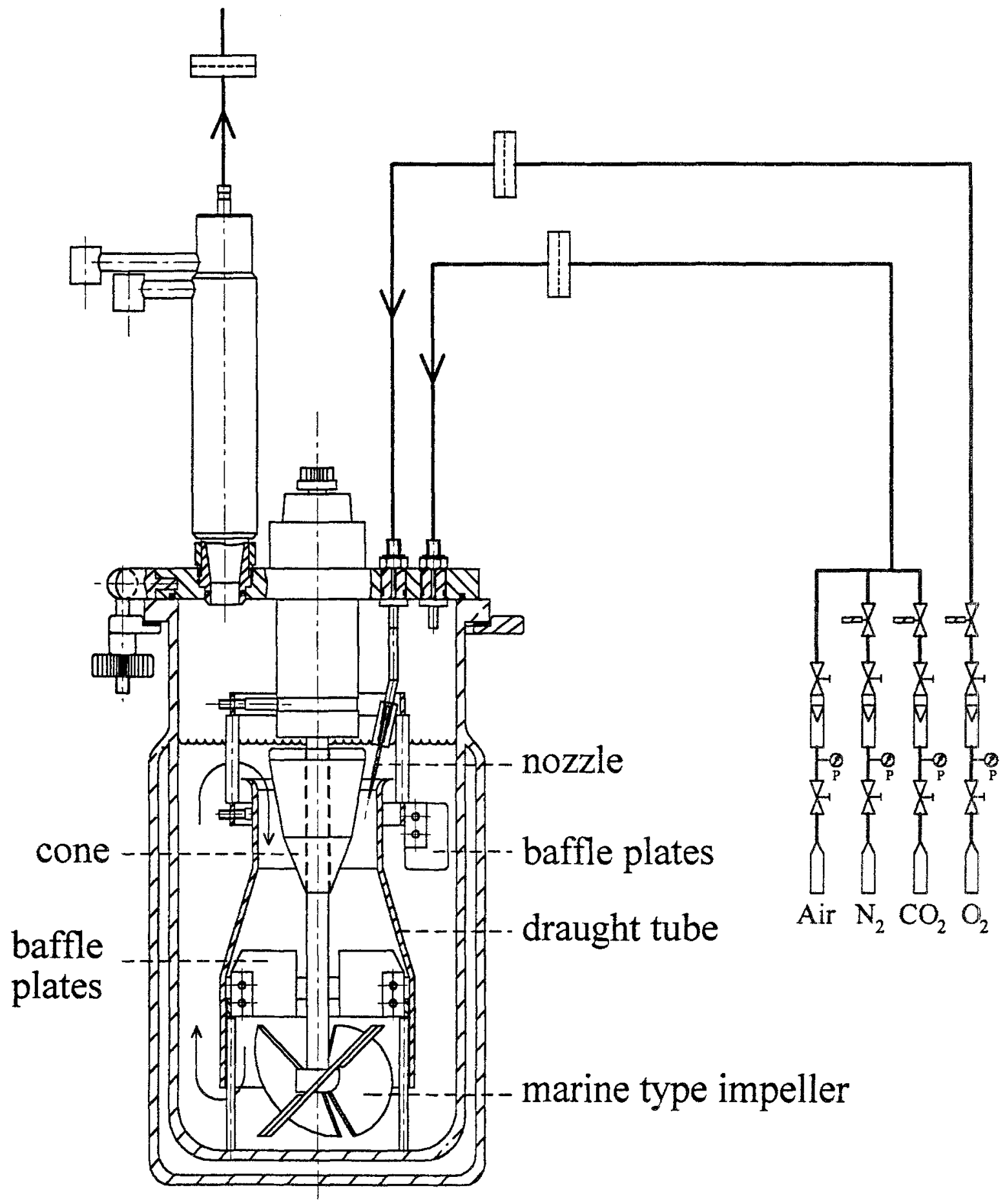

Fig. 1. Schematic diagram of the Bubble-Swarm Bioreactor. Oxygen is sparged through the nozzle into the draught tube. The shape of the draught tube and the cone mounted on the stirrer shaft create a velocity field that prevents the bubble-swarm from rising to the surface. 
In the center of the aeration unit the draught tube with its special shape is installed to build up the liquid stream described earlier. The diameter varies from $55.5 \mathrm{~mm}$ at the upper end to $85.0 \mathrm{~mm}$ at the lower end. A three-blade marine type impeller situated in the lower end generates the circular flow, which is directed downward in the inner and upward in the outer part. A cone with two different slopes reduces the upper effective aperture of the draught tube and thus increases the liquid velocity in this area of the bioreactor.

This zone of the reactor is also used for bubble formation. A glass capillary with an outer diameter of $30-50 \mu \mathrm{m}$ points downwards and is surrounded by a laminar flow. The bubbles are torn off the capillary as a result of friction force against buoyancy and surface tension. The bubbles in the draught tube are carried to the point where the downward stream velocity equals the rise velocity of the bubble caused by its buoyancy. The distance traveled by a bubble in the draught tube is thus proportional to the diameter of the bubble. A bubble-swarm builds up while sparging air or oxygen through the nozzle.

Baffle plates are placed at two different zones to reduce rotation inside the draught tube. This avoids concentration of bubbles in the center of the streamfield caused by centripetal force.

$\mathrm{pO}_{2}$ and $\mathrm{pH}$ are measured with conventional probes (Ingold, Steinbach, FRG) and controlled by a standard DCU system (B. Braun Biotech International GmbH, Melsungen, FRG). Data acquisition is carried out by a process control system (Micro MFCS, B. Braun Biotech International $\mathrm{GmbH}$, Melsungen, FRG).

\section{Measurement of the volume flow rate through the nozzle}

To determine the volume flow rate through the nozzle tip it was brought into air saturated water. Air was sparged through the capillary at a certain pressure and the bubbles built by the nozzle were caught up by a water filled glass cylinder placed above the capillary. The oxygen mass flow rate was calculated from the time needed to displace a defined volume of water.

\section{Measurement of the oxygen transfer rate OTR}

The dynamic method was used to evaluate the oxygen transfer rates. The bioreactor contained 2.3 liters of sterile basal medium at a temperature of $37^{\circ} \mathrm{C}$. The $\mathrm{pO}_{2}$ was continuously measured and the data was automatically recorded in one minute intervals by the Micro-
MFCS. First, the oxygen was displaced using nitrogen. The dynamical measurement with the calibrated electrode was then started by sparging air through the nozzle while the headspace was aerated with $10 \mathrm{l} / \mathrm{h}$ air. The effect of air sparging at different volume flow rates through the capillary on the OTR was examined.

\section{Evaluation of the efficiency of an aeration unit}

To evaluate the efficiency of the bubble-swarm aeration unit, the oxygen transfer via the liquid surface OTR $_{\text {surface }}$ under defined conditions without having any other oxygen supply or consumption was measured, first. Then, without changing the conditions of the surface aeration, the total oxygen transfer rate $\left(\mathrm{OTR}_{\text {total }}\right)$ was measured by starting the bubble-swarm aeration in the next experiment. The contribution of the bubble-swarm $\mathrm{OTR}_{\mathrm{bs}}$ can be evaluated by subtracting the contribution of the surface aeration from OTR $_{\text {total }}$

$$
\mathrm{OTR}_{\mathrm{bs}}=\mathrm{OTR}_{\text {total }}-\mathrm{OTR}_{\text {surface }}
$$

One obtains the maximum OTR were made with $\mathrm{dO}_{2}$ equal to zero. In this case

$$
\text { OTR }_{\text {bsmax }}=\mathrm{k}_{\mathrm{L}} \mathrm{a} \cdot \mathrm{c}_{\mathrm{L}}
$$

and $k_{L} a$ can be evaluated from the measured OTR $\mathrm{bsmax}_{\mathrm{bma}}$ when $\mathrm{c}_{\mathrm{L}}{ }^{*}$ is known.

The efficiency $E$ was defined as the quotient of the oxygen mass flow rate through the capillary $\mathrm{m}\left(\mathrm{O}_{2 \mathrm{cap}}\right)$ and the oxygen mass flow rate through the gas-liquid interfaces of the bubble-swarm $\mathrm{m}\left(\mathrm{O}_{2 b s}\right)$ which is proportional to OTR $\mathrm{bsmax}_{\text {. }}$

$$
\mathrm{E}=\mathrm{m}\left(\mathrm{O}_{2 \mathrm{cap}}\right) / \mathrm{m}\left(\mathrm{O}_{2 \mathrm{bs}}\right) \cdot 100
$$

The efficiency is $100 \%$ if the oxygen sparged through the nozzle is totally dissolved in the liquid. In this case $\mathrm{m}\left(\mathrm{O}_{2 \mathrm{cap}}\right)=\mathrm{m}\left(\mathrm{O}_{2 \mathrm{bs}}\right)$.

\section{Results}

Capacity and efficiency of the bubble-swarm aeration concept

It was possible to create a stationary bubble-swarm (Fig. 2) using the bioreactor geometry shown in Fig. 1. The contribution of the bubble-swarm to the oxygen transfer into the medium was examined and compared to a conventional bubble column. To evaluate 


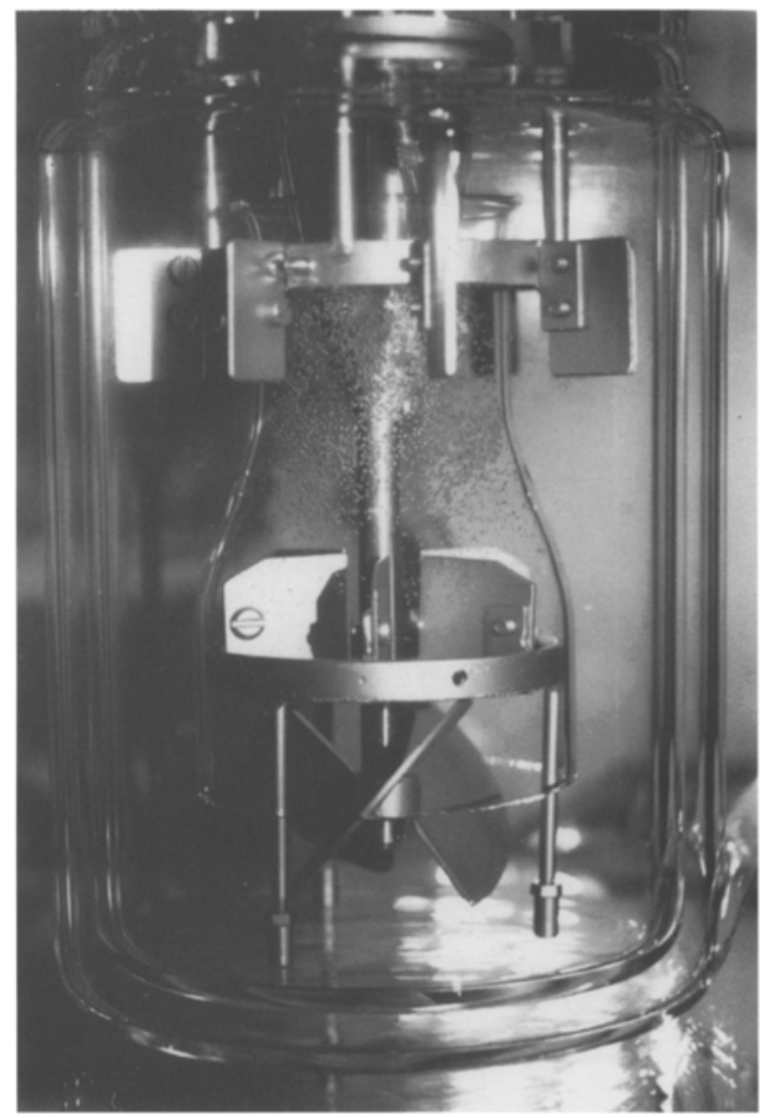

Fig. 2. Bubble-swarm formation inside the draught tube. Basal medium with $10 \mathrm{mg} / 1$ bovine insulin but without phenolred was used. The stirrer speed was set to $60 \mathrm{rpm}$.

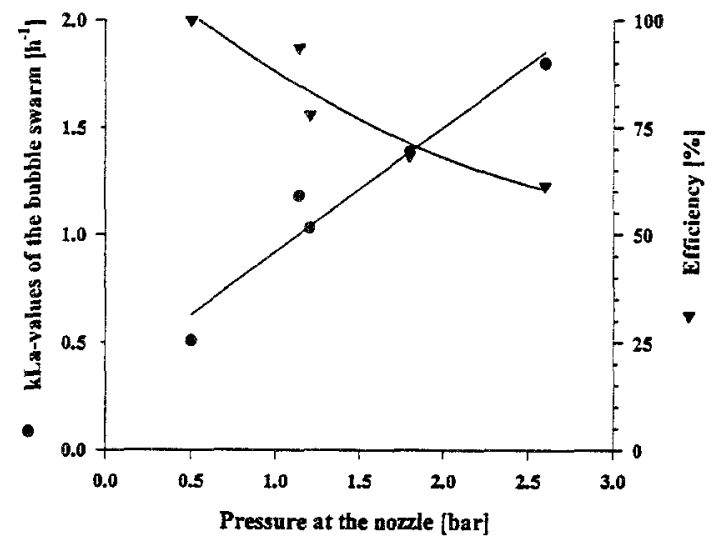

Fig. 3. The plot of the $\mathrm{k}_{\mathrm{L}}$ a-values of the bubble-swarm and the efficiency of aeration versus the pressure at the nozzle shows that increasing pressure results in increasing $\mathrm{k}_{\mathrm{L}} \mathrm{a}$-values.
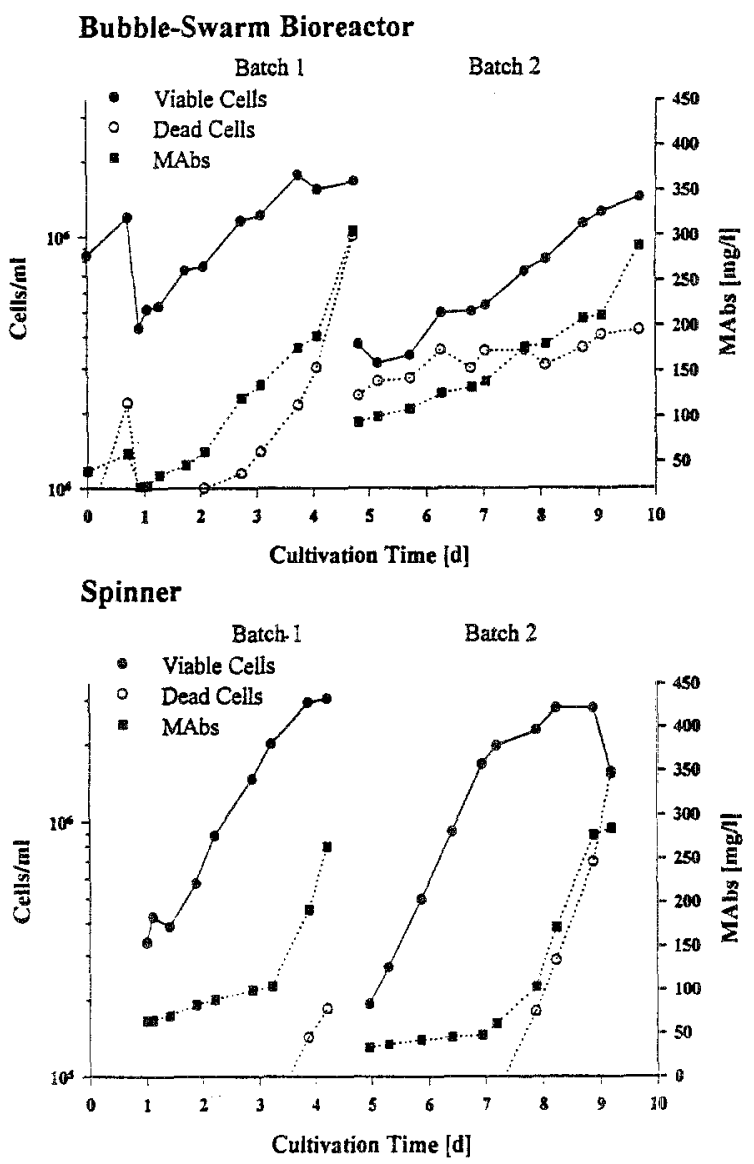

Fig. 4. Time courses of repeated batch hybridoma culivations in the Bubble-Swarm Bioreactor and a surface aerated spinner culture.

the efficiency of the system the maximum OTR of the bubble-swarm was measured by sparging air through the nozzle into sterile basal medium and aerating the headspace with $10 \mathrm{l} / \mathrm{h}$ air. The pressure at the capillary was varied from 0.5 to 2.6 bar resulting in volume flow rates through the nozzle of $0.23 \cdot 10^{-3}$ vvm to $1.26 \cdot 10^{-3} \mathrm{vvm}(32 \mathrm{ml} / \mathrm{h}-174 \mathrm{ml} / \mathrm{h})$, respectively while headspace aeration remained constant. The OTR $\mathrm{Obsmax}$ rises with increasing pressure from $110 \mu \mathrm{mol} \mathrm{O}_{2} /(1 \cdot h)$ to $388 \mu \mathrm{mol} \mathrm{O}_{2} /(\mathrm{l} \cdot \mathrm{h})$ (Fig. 3). The corresponding $\mathrm{k}_{\mathrm{L}} \mathrm{a}$ values of the bubble-swarm aeration were $0.5 \mathrm{~h}^{-1}$ up to $1.8 \mathrm{~h}^{-1}$. Evaluating the quotient of the mass flow rate through the capillary and the mass flow rate through the gas-liquid interfaces of the bubble-swarm the efficiency can be represented. At low pressure the efficiency was greater than $90 \%$. An increase in pressure results in decreasing efficiency, but at 2.6 bar still $61.4 \%$ of the oxygen carried by the air bubbles was transferred into the medium. 

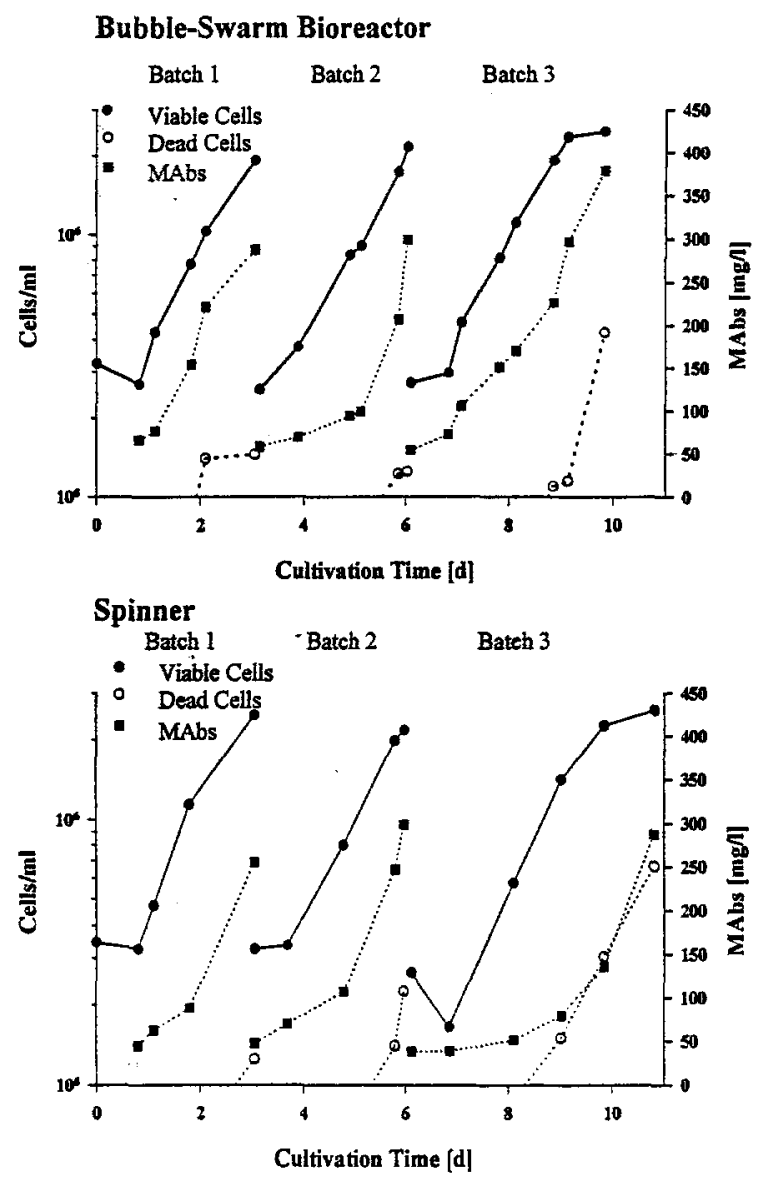

Fig. 5. Time courses of three repeated batch hybridoma cultivations in the Bubble-Swarm Bioreactor and the corresponding surface aerated spinner batch cultivations.

Zhang et al., 1992 determined the oxygen transfer rates in a bubble aerated animal cell bioreactor for different medium formulations and three different spargers. They sparged air with flow rates of $66.7 \cdot 10^{-3} \mathrm{vvm}$ to $400.0 \cdot 10^{-3} \mathrm{vvm}$ and measured $\mathrm{k}_{\mathrm{L}}$ a values ranging from about $2 \mathrm{~h}^{-1}$ (ring sparger, lowest air flow) to $75 \mathrm{~h}^{-1}$ (G-4 sinter sparger, highest air flow) in basal medium stirred with $60 \mathrm{rpm}$ at $36.5^{\circ} \mathrm{C}$. The efficiency of these systems is less than $7 \%$ with the exception of the $G-4$ sinter sparger used with a volume flow rate of $66.7 \cdot 10^{-3} \mathrm{vvm}$. This configuration reached almost $15 \%$ of efficiency. The efficiency of the ring sparger, however, never exceeded $1 \%$.

The oxygen consumption of different hybridoma cell lines varies between $130-330 \mu \mathrm{mol} \mathrm{O} \mathrm{O}_{2} /\left(10^{9}\right.$ cells'h) (Spier et al., 1984). Measurement of the oxygen uptake rate of the utilized hybridoma yielded 216 $\mu$ mol $\mathrm{O}_{2} /\left(10^{9}\right.$ cells $\left.h\right)$. Consequently, a cell density

of $1.8 \cdot 10^{6}$ cells $/ \mathrm{ml}$ could be supplied by air sparging. Utilizing pure oxygen for a cell density of up to $8.6 \cdot 10^{6}$ cells $/ \mathrm{ml}$ the oxygen supply can satisfy the oxygen demand.

\section{Cultivation 1}

To test the aeration unit and its effects on cell growth two batch cultivations were made. The BSA-free medium A which did not contain any cell protecting proteins was used first. The Bubble-Swarm Bioreactor was inoculated with $800 \mathrm{ml}$ cell suspension from a membrane aerated Super-Spinner and an additional $400 \mathrm{ml}$ of fresh medium. The cell density was $8.4 \cdot 10^{5}$ cells $/ \mathrm{ml}$. The culture was surface aerated and stirred at $60 \mathrm{rpm}$. After 18.5 hours $1100 \mathrm{ml}$ of fresh medium was added. Sparger aeration was then started with the 
Bubble-Swarm Bioreactor containing a total volume of 2.3 liters. This allowed the circulation of the fluid through the draught tube and the formation of the bubble-swarm.

Parallel to this a surface aerated spinner culture was inoculated with cells of the same Super-Spinner and the same medium that was used to inoculate the Bubble-Swarm Bioreactor. This spinner culture was used as reference for cell growth, antibody production and other metabolic parameters to those of the bubbleswarm aerated bioreactor culture.

The time courses of the first two batches in the Bubble-Swarm Bioreactor and the corresponding spinner culture are shown in Fig. 4. Cell growth was reduced in the Bubble-Swarm Bioreactor. The maximum specific growth rate $\mu_{\max }$ was $0.75 \mathrm{~d}^{-1}$, whereas $1.07 \mathrm{~d}^{-1}$ was observed in the spinner culture. Thus, one batch in the Bubble-Swarm Bioreactor took approximately one day longer than in the spinner culture. At the end of the batch the cell density in the spinner culture $\left(\sim 3 \cdot 10^{6}\right.$ cells $\left./ \mathrm{ml}\right)$ was two times higher than in the Bubble-Swarm Bioreactor. Also the viability was higher in the spinner culture. Only at the end of the logarithmic growth phase did the number of dead cells exceed $2 \cdot 10^{5}$ cells $/ \mathrm{ml}$, whereas this value was already reached in the logarithmic growth phase of the Bubble-Swarm Bioreactor culture. In spite of different antibody production rates of $108.8 \mathrm{mg} /\left(10^{9}\right.$ cells $\left.\cdot d\right)$ for the spinner culture and $71.3 \mathrm{mg} /\left(10^{9}\right.$ cells $\left.\cdot \mathrm{d}\right)$ for the Bubble-Swarm Bioreactor culture, the antibody concentration at the end of the batch was about $300 \mathrm{mg} / \mathrm{l}$ in both systems, due to different batch duration.

\section{Cultivation 2}

To examine the influence of higher protein concentration on cell viability medium B (containing $500 \mathrm{mg} / \mathrm{l}$ BSA) was utilized for the second cultivation in the Bubble-Swarm Bioreactor and the spinner culture.

Figure 5 compares three repeated batches of the Bubble-Swarm Bioreactor and three batches of the surface aerated spinner. Batch durations, final cell densities, viability and final antibody concentration were approximately the same in both systems.

A detailed consideration of the third batch of the Bubble-Swarm Bioreactor cultivation and the corresponding spinner batch is plotted in Fig. 6. Glucose consumption and lactate production in the BubbleSwarm Bioreactor were of the same order as those in the spinner culture (Table 1).
The electrode readings of the controlled oxygenand $\mathrm{pH}$-values during the third batch in the BubbleSwarm Bioreactor are plotted in Fig. 7. In the first phase mixed gas (air, nitrogen and $\mathrm{CO}$,) was sparged through the nozzle with constant pressure and was also used for headspace aeration $72.5 \cdot 10^{-3} \mathrm{vvm}(10 \mathrm{l} / \mathrm{h})$. At day 8 of the cultivation pure oxygen was sparged through the nozzle to supply the cell culture. $\mathrm{pH}$ control, especially $\mathrm{CO}_{2}$ removement was performed via the headspace $(20 \mathrm{l} / \mathrm{h}$ air). From this point on oxygen supply and $\mathrm{CO}_{2}$ exchange were separated. Unfortunately, it was not possible to control the pressure at the nozzle dependent on the actual $\mathrm{pO}_{2}$-level with the standard DCU system. A certain pressure was chosen and kept constant for hours, so drops of the $\mathrm{pO}_{2}$-llevel were caused by an altered oxygen demand of the culture due to cell growth. At the end of the batch it was difficult to choose a suitable pressure to supply the cell culture with the result of an alterating $\mathrm{pO}_{2}$-level.

\section{Discussion}

The bubble-swarm aeration method was able to supply the cell culture with oxygen, but $\mathrm{CO}_{2}$, had to be removed via the surface, because only a small percentage of the gas sparged into the medium reached the surface. The Bubble-Swarm Bioreactor cultivations showed that it was possible to control the $\mathrm{pH}$-level up to a cell density of $2.5 \cdot 10^{6}$ cells $/ \mathrm{ml}$.

In contrast to the calculations above only $2 \cdot 10^{6}$ cells $/ \mathrm{ml}$ can be supplied with oxygen at a pressure of 2.6 bar applied to a capillary that has already been used for three weeks. The reason for the reduced gas flow rates through the nozzle after a certain period of time might be attributed to attached cells at the capillary surface. At the end of the cultivation the used nozzle was overgrown with cells. Especially the fine tip of the capillary and parts of the aperture were coated.

During the OTR measurements and the two Bubble-Swarm Bioreactor cultivations significant foam formation did not occur. While sparging with $1.50 \cdot 10^{-3} \mathrm{vvm}(207 \mathrm{ml} / \mathrm{h})$ foam formation reached its maximum, but even then only a monolayer of small bubbles coated the surface. This shows that the addition of foam regulating surfactants was not necessary when using the bubble-swarm aeration unit.

Nevertheless, BSA has to be added to the serumfree medium to protect the cells against shear forces. Cell damage occurs in the Bubble-Swarm Bioreactor only while using medium A with a very low protein 


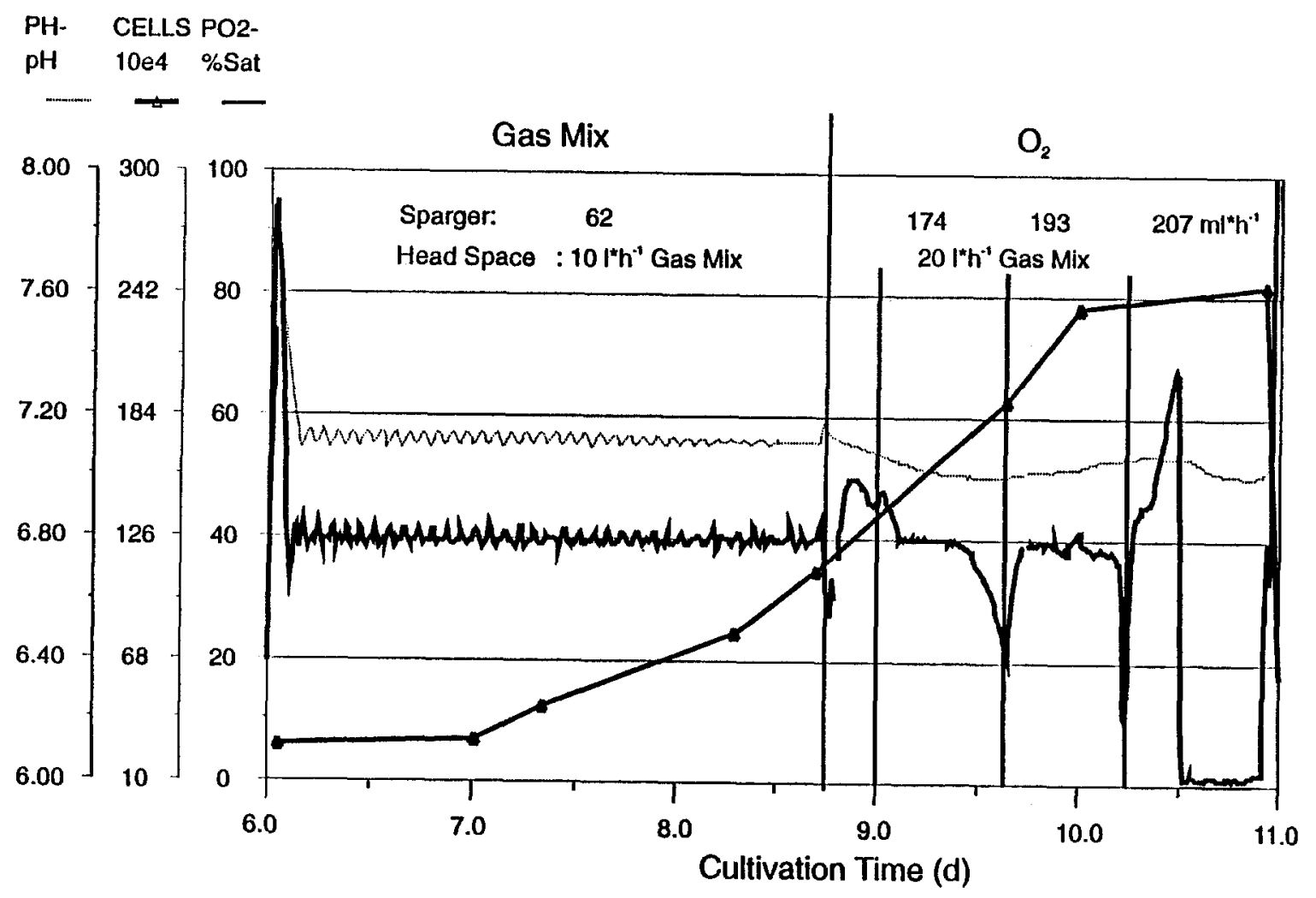

Fig. 7. Time plot of the cell density and controlled $\mathrm{pO}_{2}$ - and $\mathrm{pH}$-values during the third batch of the Bubble-Swarm Bioreactor cultivation of Fig. 5.

Table 1. Comparison of specific growth rate, antibody production and metabolic rates in the third batch of the cultivation in the Bubble-Swarm Bioreactor and the corresponding spinner control batch shown in Fig. 5.

\begin{tabular}{llllll}
\hline & $\begin{array}{l}\mu_{\max } \\
{\left[\mathrm{d}^{-1}\right]}\end{array}$ & $\begin{array}{l}\mathrm{q}_{\mathrm{MAbs}} \\
{\left[\mathrm{mg} /\left(10^{9} \cdot \text { cell } \cdot \mathrm{d}\right)\right]}\end{array}$ & $\begin{array}{l}\mathrm{q}_{\mathrm{Glucose}} \\
{[\mathrm{mmol} /(\mathbf{1 0} \cdot \mathrm{cells} \cdot \mathrm{d})]}\end{array}$ & $\begin{array}{l}\mathrm{q}_{\text {Lactate }} \\
{\left[\mathrm{mmol} /\left(10^{9} \cdot \mathrm{cells} \cdot \mathrm{d}\right)\right]}\end{array}$ & $\begin{array}{l}\mathrm{q}_{\text {Ammonia }} \\
{\left[\mathrm{mmol} /\left(10^{9} \cdot \mathrm{cells} \cdot \mathrm{d}\right)\right]}\end{array}$ \\
\hline $\begin{array}{l}\text { Bubble-Swarm Bioreactor } \\
\text { Spinner culture }\end{array}$ & 0.87 & 139.4 & 5.78 & 7.16 & 2.69 \\
\hline
\end{tabular}

content (cultivation 1). The fact that the addition of BSA did not affect the foam formation in the BubbleSwarm Bioreactor cultivation, especially a foam reduction was not observed, showed that the higher growth rate of cultivation 2 cannot be related to an altered foam formation. This indicates that shear forces e.g. in the zone of high velocity which is located in the upper part of the draught tube were the reason of the reduced cell growth in cultivation 1 .

Small bubbles with low rise velocities are the assumption of the formation of a bubble-swarm. The diameter of the bubbles build by a nozzle is propor- tional to the radius of its orifice. So capillaries with small outer diameters are required. A nozzle with a radius of $5 \mathrm{~m}$ built the smallest bubbles but showed a high tendency of clogging. In order to prevent clogging the orifice diameter in the final aeration unit is set to $30-50 \mu \mathrm{m}$. This also yields a suitable bubble size and gas flow rate. Both cultivations and the necessary calibrations were made with the same nozzle, sparging continuously for more than three weeks without having to be cleaned. 


\section{Conclusion}

The aeration of a bioreactor with a stationary bubbleswarm satisfied the special demands of mammalian cell cultures. A rat-mouse hybridoma cell line was successfully cultivated in serum-free medium. The comparison of the Bubble-Swarm Bioreactor cultivated cells with those, grown in a spinner bottle showed no changes of physiological parameters when BSA containing serum-free medium was used. The high efficiency of the system allowed sparging with low gas flow rates, thus only a small amount of oxygen was needed to supply the cell culture. It was also possible to reduce the gas flow rate from the liquid into the headspace, because bubble disengagement at the surface was minimized, due to high efficiency. This led to a suppression of foam formation without using additional surface active substances for foam regulation.

Further work will concentrate on an alternative nozzle material that prevents cell attachment, optimization of hydrodynamical parameters (impeller or draught tube geometry) and the development of a pressure control system.

\section{References}

Büntemeyer H, Lütkemeyer D and Lehmann J (1991) Optimization of serum-free fermentation processes for antibody production. Cytotechnology 5: 57-67.

Handa A, Emery AN and Spier RE (1985) On the evaluation of gasliquid interfacial effects on hybridoma viability in bubble column bioreactors. Develop. Biol. Standard. 66: 241-253.

Handa-Corrigan A, Emery AN and Spier RE (1989) Effect of gasliquid interfaces on the growth of suspended mammalian cells: mechanisms of cell damage by bubbles. Enzyme Microb. Technol. 11: 230-235.
Heidemann R, Riese U, Lütkemeyer D, Büntemeyer H and Lehmann J (1994) The Super-Spinner: a low cost animal cell culture bioreactor for the $\mathrm{CO}_{2}$, incubator. Cytotechnology 14: 1-9.

Hülscher $M$ and Onken U (1988) Influence of bovine serum albumin on the growth of hybridoma cells in airlift loop reactors using serum-free medium. Biotechnology Letters 10: 689-694.

Jäger V, Lehmann J and Friedl P (1988) Serum-free growth medium for the cultivation of a wide spectrum of mammalian cells in stirred bioreactors. Cytotechnology 1: 319-329.

Jäger V (1991) Serum-free media suitable for upstream and downstream processing. In: Spier RE, Griffiths JB, Meignier B (eds.) Production of Biologicals from Animal Cells in Culture. Research, Development and Achievements. Butterworths, Kent, UK.

Jöbes I, Martens D and Tramper J (1991) Lethal events during gas sparging in animal cell culture. Biotechnol. Bioeng. 37: 484-490.

Lehmann J, Heidemann R, Riese U, Lütkemeyer D and Büntemeyer H (1992) Der Superspinner. Ein 'Brutschrank-Fermenter' für die Massenkultur tierischer Zellen. Bioengineering 5+6: 36-38.

Oh SKW, Nienow AW, Al-Rubeai M and Emery AN (1992) Further studies of the culture of mouse hybridomas in an agitated bioreactor with and without continuous sparging. J. Biotechnol. 22: 245-270.

Ozturk SS and Palsson BO (1991) Examination of serum and bovine serum albumin as shear protective agents in agitated cultures of hybridoma cells. J. Biotechnol. 18: 13-28.

Prins A and van 't Riet K (1987) Proteins and surface effects in fermentation: foam, antifoam and mass transfer. Tibtech 5: 296301.

Spier RE, Griffiths JB (1984) An examination of the data and concepts germane to the oxygenation of cultured animal cells. Dev. Biol. Standard. 55: 81-92.

Zhang S, Handa-Corrigan A and Spier RE (1992) Foaming and media surfactant effects on the cultivation of animal cells in stirred and sparged bioreactors. J. Biotechnol. 25: 289-306.

Zhang S, Handa-Corrigan A and Spier RE (1992) Oxygen transfer properties of bubbles in animal cell culture. Biotechnol. Bioeng. 40:252-259.

Address for offprints: F. Gudermann, University of Bielefeld, Technical Faculty, Institute of Cell Culture Technology, P.O. Box 1001 31, 33501 Bielefeld, Germany. 